3 Markin KE. Wolst MD. A comparative controlled study of hormones used in he prevention of postpartum breast engorgement and lactation. Am $7 \mathrm{Obstet}$ Gynecol 1960;80:128-37.

4 Daniel DG, Campbell H, Turnbell AC. Puerperal thromboembolism and suppression of lactation. Lancet 1967;ii:287-92.

5 Tindall VR. Factors influencing puerperal thrombo-embolism. fournal of Obstetrics and Gynaecology of the British Commonwealth 1968;75:1324-7.

6 Rolland R. Use of bromocriptine in the inhibition of puerperal lactation. Drugs 1979;17:326-36.

7 Peters F, Del Pozo E, Conti A, Breckwoldt M. Inhibition of lactation by a longacting bromocriptine. Obstet (jynecol 1986;67:82-5.

Duchesne C, Leke R. Bromocriptine mesvlate for prevention of postpartum lactation. Obstet (jynecol 1981;57:464-7.

9 Parlodel S. Physician's desk reference. 43rd ed. New York: Medical Economics, 1989.

10 Crosignani PG, Lombroso GC, Caccamo A, Reschini E, Peracchi $M$ Suppression of puerperal lactation by metergoline. Obstet Gynecol 1978;51: Suppre.

11 Van Dam LJ, Rolland R. Lactation-inhibiting and prolactin-lowering effect of lisuride and bromocriptine: a comparative study. Eur f Obstet Gynecol lisuride and bromocriptine:

2 Lancranjan I, Rolland R, L'Hermite M. Inhibition of lactation with depot bromocriptine. Ann NY Acad Sci 1986;464:473-7.
13 Di Salle E, Ornati G, Briatico G. FCE 21336, a new ergoline derivative with a Sotent and long-acting lowering effect on prolactin secretion in rats. Findocring lost 1982,5 (suph 1 ): 45 .

14 Ferrari C, Barbieri C, Caldara R, et al. Long-lasting prolactin-lowering effec of cabergoline, a new dopamine agonist, in hyperprolactinemic patients. f Clin Endocrinol Metab 1986;63:941-5.

15 Melis GB, Mais V, Paoletti AM, Benvenuti F, Gambaccioni M, Fioretti P. Prevention of puerperal lactation by a single oral administration of the new prolactin-inhibiting drug, cabergoline. Obstet Gynecol 1988;71:311-4.

16 Caballero Gordo A, Lopez-Lazareno N, Calderay M, Caballero Gordo JL, Mancheno E, Sghedoni D. Cabergoline: oral single dose inhibition of puerperal lactation. F Reprod Med (in press).

17 Blackwelder WC. "Proving the null hypothesis" in clinical trials. Controlled Clin Trials 1982;3:345-5

18 Dunnet $\mathrm{CW}$, Gent $\mathrm{M}$. Significance testing to establish equivalence between treatments, with special reference to data in the form of $2 \times 2$ tables. Biometrics 1977;33:593-602.

19 Mantel N, Haenszel W Statistical aspects of the analysis of data from retrospective studies of disease. F Natl Cancer Inst 1959:22:719-48.

20 Miller RG. Simultaneous statistical inference. New York: Springer-Verlag, 1981.

(Accepted 12 March 1991)
Icelandic Heart

Association, Lagmula 9,

Reykjavik, Iceland

Nikulas Sigfusson, MD,

chief physician

Helgi Sigvaldason, PHD,

statistician

Inga Ingibjörg

Gudmundsdottir, BSC,

research assistant

Ingibjörg Stefansdottir, BSC, research assistant

Thorsteinn Thorsteinsson,

MSC, chief biochemist

Icelandic Nutritional

Council, Armula 1a,

Reykjavik, Iceland

Laufey Steingrimsdottir,

PHD, nutritional physiologist

Department of Medicine, Reykjavik City Hospital,

108 Reykjavik, Iceland

Gunnar Sigurdsson, MD,

chief physician

Correspondence to:

Dr Sigurdsson.

BMf 1991;302:1371-5

\title{
Decline in ischaemic heart disease in Iceland and change in risk factor levels
}

Nikulas Sigfusson, Helgi Sigvaldason, Laufey Steingrimsdottir, Inga Ingibjörg Gudmundsdottir, Ingibjörg Stefansdottir, Thorsteinn Thorsteinsson, Gunnar Sigurdsson

\section{Abstract}

Objective-To monitor trends in mortality and morbidity due to ischaemic heart disease and compare these with observed levels of risk factors from population surveys.

Design-Analysis of trends in death rates from ischaemic heart disease in Iceland compared with expected rates computed from population surveys. Risk factor levels together with $\beta$ factors obtained from Cox's regression analysis were used to compute expected death rates. Trends in morbidity due to acute myocardial infarction were assessed and secular trends in dietary consumption compared with trends in cholesterol concentrations.

Setting-Reykjavik, Iceland (total population 250000 ; over half the population live in Reykjavik).

Subjects -12814 randomly selected residents in the Reykjavik area aged 45-64 (6623 men, 6191 women; $72 \%$ and $80 \%$ of those invited).

Main outcome measures-Age adjusted rates of myocardial infarction and deaths from ischaemic heart disease. Expected risk from risk factor levels (smoking, total serum cholesterol concentration, systolic blood pressure) at each unique survey visit.

Results-Mortality from ischaemic heart disease has decreased by $17-18 \%$ since 1970 . During 1981-6 the myocardial infarction attack rate in men under 75 decreased by $23 \%$. A decrease occurred in the level of all three major risk factors after 1968 . The fall in the serum cholesterol concentration coincided with a reduction in consumption of dairy fat and margarine. The calculated reduction in risk for the age group 45-64 was about $35 \%$, which was closely similar to the observed decrease in mortality due to ischaemic heart disease in that age group.

Conclusion-The reduction in mortality from ischaemic heart disease was substantially due to a decreased incidence of myocardial infarction and could be attributed largely to the reduction in risk factors.

\section{Introduction}

The mortality from ischaemic heart disease has been declining in some countries and holding steady in others, but in a few countries it continues to rise. ${ }^{1}$ Time trends or secular trends in ischaemic heart disease mortality have been difficult to analyse because they are usually based on mortality statistics with little or no information about the individual changes in the pattern of risk factors.

Mortality from ischaemic heart disease in Iceland is similar to that in other Scandinavian countries. ${ }^{1}$ We have analysed the trends in mortality and morbidity due to ischaemic heart disease in Iceland in relation to changes in $(a)$ the three major risk factors for the disease as documented in population surveys from 1968 to 1988 - namely, smoking, total serum cholesterol concentration, and systolic blood pressure-and (b) the consumption of saturated fats.

\section{Subjects and methods}

\section{ASCERTAINMENT OF MORTALITY FIGURES}

Information was obtained from all death certificates from 1951 to 1988 on file in the Statistical Bureau of Iceland by using the following codes of the International Classification of Diseases: 1951-60, ICD (sixth revision) code 420 ; 1961-70, ICD (seventh revision) code 420; 1971-80, ICD (eighth revision) codes 410-413; 1981-8, ICD (ninth revision) codes 410-414. These codes have been suggested to be the most equivalent for ischaemic heart disease in the different editions. ${ }^{2}$ All death certificates were reviewed and coded by an official pathologist. Necropsy had been carried out in $30-40 \%$ of cases.

\section{REGISTER OF MYOCARDIAL INFARCTION 1981-6}

During 1981-6 all episodes of acute myocardial infarction in people aged 25-74 anywhere in Iceland were registered by the Icelandic study group of the World Health Organisation's MONICA project (multinational monitoring of trends and determinants of cardiovascular disease). ${ }^{3-5}$ Diagnostic criteria included symptoms, electrocardiograms, enzyme activities, and necropsy findings compatible with definite or possible myocardial infarction (category I or II). ${ }^{45}$ External quality control of event registration was performed by the WHO's reference centre in Dundee. Registrations included all occurrences of acute myocardial infarction (and sudden ischaemic cardiac death), but also, as separate categories, first and recurrent infarctions (more than 28 days apart). The proportion of cases excluded because of inade- 
quate data was $2 \%$. Only data for men were used in this analysis because of the small number of coronary episodes among women.

\section{SECULAR TRENDS IN RISK FACTORS 1968-88}

The Icelandic Heart Association Research Centre has been conducting a prospective population survey in Reykjavik since 1968 (Reykjavik study). Over half of the quarter of a million population of Iceland live in the Reykjavik area. Icelanders, however, are almost homogeneous ethnically (of Nordic origin) and have closely similar living habits (and risk factor levels; unpublished results). The standard of living in Iceland has been increasing steadily during the observation period and is comparable with that in other Scandinavian countries. This study examines the three main factors found to be associated with increased risk of ischaemic heart disease death in the Icelandic population $^{6}$ (unpublished results)-namely, total serum cholesterol concentrations, smoking, and systolic blood pressure.

Data were obtained at baseline in stages I-IV of the Reykjavik study on a random sample of the general population in the area. The participation rate was $72 \%$ and $80 \%$ of the men and women invited. In addition, data from the MONICA risk factor surveys in Iceland during 1983 (survey I) and 1988 (survey II), also conducted by the Icelandic Heart Association Research Centre, were used (table I). Each survey sample comprised a unique group of participants. The age group 45-64 years was chosen as it was common to all these surveys. Age adjustment was performed by using the mean of the age specific values for the four five year age groups. Each of the four age groups was examined and the trends found to be similar.

Total serum cholesterol concentration was measured after overnight fasting. In stages of I-IV at the Reyk-

TABLE I -Numbers of men and women aged 45-64 who participated in population surveys in Iceland during 1968-88

\begin{tabular}{lccccr}
\hline & \multicolumn{2}{c}{ Men } & & \multicolumn{2}{c}{ Women } \\
\cline { 2 - 3 } \cline { 5 - 6 } Survey & $\begin{array}{c}\text { Year of } \\
\text { examination }\end{array}$ & No & & $\begin{array}{c}\text { Year of } \\
\text { examination }\end{array}$ & No \\
\hline Reykjavik study stage I & 1968 & 1416 & & 1969 & 1535 \\
Reykjavik study stage II & $1970-1$ & 1599 & & $1971-2$ & 1756 \\
Reykjavik study stage III & $1974-6$ & 1646 & & $1976-8$ & 739 \\
Reykjavik study stage IV & $1979-81$ & 1089 & & $1982-3$ & 1228 \\
MONICA I & 1983 & 444 & & 1983 & 468 \\
MONICA II & 1988 & 429 & 1988 & 465 \\
\hline
\end{tabular}

javik study and in MONICA I cholesterol was determined by a chemical colorimetric method (Technicon autoanalyser method $\mathrm{N}-24 \mathrm{a}) .^{7}$ In MONICA II an automated enzymatic method was used (Roche MA 30; Cobas, Mira). In 250 serum samples subjected to both methods of measurement results showed close agreement, the mean total cholesterol concentration being $6.37 \mathrm{mmol} / \mathrm{l}$ by the chemical method and $6.33 \mathrm{mmol} / \mathrm{l}$ by the enzymatic method $(\mathrm{r}=0.93)$. Internal and external laboratory quality controls were used.

Systolic blood pressure was measured by a mercury sphygmomanometer (Erka) after five minutes' rest. Information on smoking habits and use of antihypertensive agents was obtained from a health questionnaire. $^{8}$

The predicted risk associated with each risk factor was calculated from (a) $\beta$ coefficients (see table II) derived from multivariate analysis using Cox's proportional hazard model $^{9}$ of survival in an Icelandic prospective population survey (1968-85; comprising 15000 men and 16000 women, of whom 493 and 104 respectively died of ischaemic heart disease) and $(b)$ the level of these risk factors for each person in the first examination at the Icelandic Heart Association Research Centre ${ }^{6}$ (unpublished results).

\section{SECULAR TRENDS IN DIETARY FAT CONSUMPTION}

A national survey showed that milk, butter, other dairy products, margarine, meat, and meat products together contribute $90 \%$ of saturated fat in the Icelandic diet. ${ }^{10}$ In this study changes in the consumption of these foods were assessed on the basis of annual sales and production records from the Agricultural Production Board (dairy and meat products) ${ }^{11}$ and annual production records from the Statistical Bureau of Iceland (margarine). ${ }^{12}$ These data reflect actual consumption as Iceland is totally self sufficient in these products and prohibits all import of meat and dairy products. Furthermore, all food exports and reserves were excluded from these data. No imports or exports of margarine occurred during the years covered by the study. Finally, dietary fat from these products was calculated by using Icelandic food composition tables.

\section{STATISTICS}

Secular trends during a defined period were determined by linear regression. Levels of significance were computed with two tailed $t$ tests. In establishing

TABLE II-Major risk factors for ischaemic heart disease deaths in Icelandic men and women aged 45-64 examined during 1968-88 (men) and 1969-88 (women)

\begin{tabular}{|c|c|c|c|c|c|c|c|c|c|}
\hline \multirow[b]{3}{*}{ Survey } & \multirow[b]{3}{*}{$\begin{array}{l}\text { Years of } \\
\text { examination }\end{array}$} & \multicolumn{4}{|c|}{ Smoking } & \multirow[b]{3}{*}{$\begin{array}{l}\text { Mean systolic blood } \\
\text { pressure (mm Hg) }\end{array}$} & \multirow[b]{3}{*}{$\begin{array}{c}\text { \% Taking } \\
\text { antihypertensive } \\
\text { drugs }\end{array}$} & \multirow[b]{3}{*}{$\begin{array}{c}\text { Mean serum } \\
\text { cholesterol } \\
(\mathrm{mmol} / \mathrm{l})\end{array}$} & \multirow{3}{*}{$\begin{array}{c}\text { Relative risk } \\
\text { explained by risk } \\
\text { factors } \\
\text { (95\% confidence } \\
\text { interval) }\end{array}$} \\
\hline & & \multirow[b]{2}{*}{$\begin{array}{c}\% \\
\text { Never } \\
\text { smokers }\end{array}$} & \multirow[b]{2}{*}{$\begin{array}{c}\% \\
\text { Former } \\
\text { s smokers }\end{array}$} & \multicolumn{2}{|c|}{ Smokers } & & & & \\
\hline & & & & $\begin{array}{l}\text { \% Smoking } 1 / 24 \\
\text { cigarettes daily or } \\
\text { cigars or pipe }\end{array}$ & $\begin{array}{l}\% \text { Smoking } \geqslant 25 \\
\text { cigarettes daily }\end{array}$ & & & & \\
\hline \multicolumn{10}{|c|}{ Men } \\
\hline Reykjavik study stage I & 1968 & $19 \cdot 0$ & $22 \cdot 9$ & $53 \cdot 5$ & $4 \cdot 6$ & $139 \cdot 2$ & $5 \cdot 9$ & $6 \cdot 65$ & 1.00 \\
\hline Reykjavik study stage II & $1970-1$ & $22 \cdot 1$ & $22 \cdot 7$ & $51 \cdot 0$ & $4 \cdot 3$ & $149 \cdot 4$ & $4 \cdot 3$ & $6 \cdot 47$ & $1.01(0.94$ to 1.08$)$ \\
\hline Reykjavik study stage III & $1974-6$ & $22 \cdot 4$ & $23 \cdot 0$ & $49 \cdot 0$ & $5 \cdot 5$ & $143 \cdot 8$ & $6 \cdot 7$ & 6.46 & $0.94(0.88$ to 1.00$)$ \\
\hline Reykjavik study stage IV & $1979-81$ & $16 \cdot 4$ & $26 \cdot 6$ & $44 \cdot 0$ & $13 \cdot 0$ & $135 \cdot 3$ & $8 \cdot 5$ & $6 \cdot 17$ & $0.80(0.72$ to 0.88$)$ \\
\hline MONICA I & 1983 & $26 \cdot 9$ & $37 \cdot 5$ & $30 \cdot 4$ & $5 \cdot 2$ & $130 \cdot 1$ & $10 \cdot 8$ & $6 \cdot 38$ & $0.72(0.67$ to 0.79$)$ \\
\hline MONICA II & 1988 & $34 \cdot 5$ & $32 \cdot 9$ & $25 \cdot 4$ & $7 \cdot 2$ & $131 \cdot 3$ & $12 \cdot 6$ & $6 \cdot 18$ & $0.67(0.62$ to 0.73$)$ \\
\hline Change in risk factor over 2 & yearst & $12 \cdot 0$ & $13 \cdot 7$ & $-29 \cdot 3$ & $3 \cdot 6$ & $-15 \cdot 5$ & $7 \cdot 4$ & -0.42 & \\
\hline \multicolumn{2}{|c|}{$\beta$ Coefficient from Cox's regression } & 0 & $0 \cdot 34$ & $0 \cdot 79$ & $1 \cdot 07$ & $0 \cdot 012$ & $0 \cdot 64$ & 0.366 & \\
\hline \multicolumn{2}{|l|}{$\%$ Change in explained risk } & \multirow{2}{*}{\multicolumn{3}{|c|}{-13}} & & -17 & 7 & -14 & -34 \\
\hline \multicolumn{7}{|c|}{ Women } & & & \\
\hline Reykjavik study stage I & 1969 & $43 \cdot 4$ & $13 \cdot 0$ & $41 \cdot 5$ & $2 \cdot 0$ & $141 \cdot 9$ & $7 \cdot 9$ & $7 \cdot 16$ & 1.00 \\
\hline Reykjavik study stage II & $1971-2$ & $46 \cdot 9$ & $11 \cdot 9$ & $39 \cdot 7$ & 1.5 & $149 \cdot 6$ & $10 \cdot 3$ & 6.94 & $1.09(0.97$ to 1.22$)$ \\
\hline Reykjavik study stage III & $1976-8$ & $44 \cdot 1$ & 14.9 & $38 \cdot 2$ & $2 \cdot 7$ & $130 \cdot 1$ & $10 \cdot 1$ & $6 \cdot 61$ & $0.72(0.66$ to 0.79$)$ \\
\hline Reykjavik study stage IV & $1982-3$ & $40 \cdot 0$ & $16 \cdot 4$ & $38 \cdot 6$ & 4.9 & $129 \cdot 8$ & $11 \cdot 3$ & $6 \cdot 28$ & $0.69(0.62$ to 0.77$)$ \\
\hline MONICA I & 1983 & $46 \cdot 0$ & $21 \cdot 1$ & $31 \cdot 7$ & $1 \cdot 2$ & $129 \cdot 3$ & $18 \cdot 8$ & $6 \cdot 74$ & $0.70(0.63$ to 0.78$)$ \\
\hline MONICA II & 1988 & $.52 \cdot 5$ & $17 \cdot 0$ & $28 \cdot 6$ & $2 \cdot 2$ & $128 \cdot 9$ & $17 \cdot 2$ & $6 \cdot 38$ & $0.64(0.56$ to 0.73$)$ \\
\hline \multirow{2}{*}{\multicolumn{2}{|c|}{$\begin{array}{l}\text { Change in risk factor over } 19 \text { yearst } \\
\beta \text { Coefficient from Cox's regression }\end{array}$}} & 4.5 & $6 \cdot 7$ & $-11 \cdot 8$ & $0 \cdot 8$ & $-19 \cdot 3$ & $9 \cdot 5$ & -0.75 & \\
\hline & & 0 & $0 \cdot 19$ & 1.06 & $1 \cdot 98$ & 0.014 & $0 \cdot 64$ & $0 \cdot 25$ & \\
\hline \multicolumn{2}{|l|}{$\%$ Change in explained risk } & & & -8 & & -24 & 8 & -17 & -37 \\
\hline
\end{tabular}


confidence intervals for rates and ratios between rates their logarithm was assumed to follow the normal distribution and its variance estimated as the sum of reciprocals of the underlying number of individuals. ${ }^{1314}$ Variance of the estimates of risk explained by the risk factors was computed directly from the risk in the individuals in each survey. The risk in each individual was computed relative to the risk in a person having never smoked, not taking antihypertensive drugs, having a total serum concentration cholesterol of $6.5 \mathrm{mmol} / \mathrm{l}$, and having a systolic blood pressure of $140 \mathrm{~mm} \mathrm{Hg}$.

\section{Results}

\section{MORTALITY FIGURES}

Figure 1 shows the secular trends from 1951 to 1988 of death rates in Iceland due to ischaemic heart disease age standardised to the world population. ${ }^{15}$ The maximum rate was reached after 1965 for both sexes and rates then remained steady until after 1985 . A significant reduction occurred during 1986-8 compared with $1981-5$ - namely, a $17 \%$ reduction among men and a $12 \%$ reduction among women. The death rate during 1986-8 was similar to that in the early 1960s. In women mortality fell by $18 \%$ between 1970 and 1986-8. Analysis of age specific mortality showed that this reduction had already occurred during 1980-5 in age groups under 75 but no decrease occurred in the oldest age groups (data not shown).

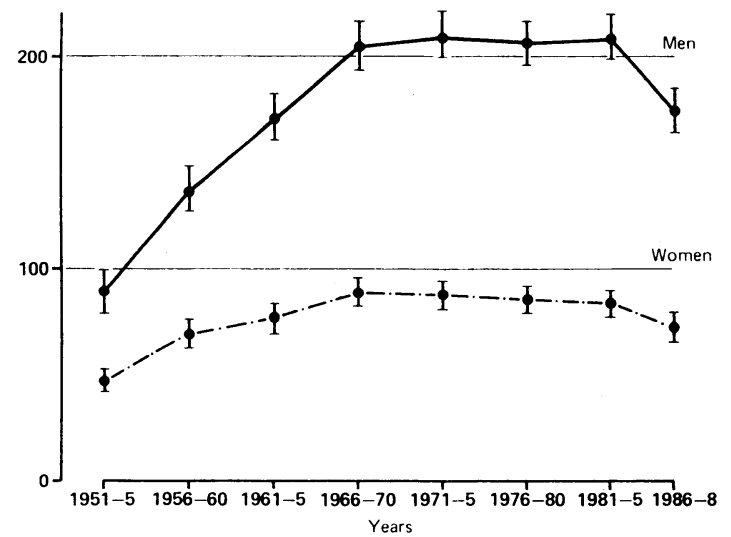

FIG 1-Ischaemic heart disease mortality in Iceland during 1951-88 standardised to world population and expressed per 100000 population yearly. Bars are $95 \%$ confidence intervals

\section{MYOCARDIAL INFARCTION 1981-6}

Time trends in rates for myocardial infarction during 1981-6 were calculated from the regression lines shown in figure 2 . The attack rate of myocardial infarction in men aged $25-74$ decreased by $23 \%$ $(p=0.02)$, the incidence rate of myocardial infarction by $19 \%(p=0.015)$, and the total death rate from ischaemic heart disease (myocardial infarction plus sudden ischaemic cardiac death) by $34 \%(\mathrm{p}=0.04)$ (fig $2)$. The case fatality rate for men was $45 \%(194 / 432)$ in 1981 and $36 \%(125 / 343)$ in 1986 , but this difference was not significant $(p=0 \cdot 14)$. Episodes of recurrent myocardial infarction did not decrease significantly more than the incidence of myocardial infarction $(30 \%$ $v 19 \% ; \mathrm{p}=0 \cdot 35$ ).

\section{SECULAR TRENDS IN RISK FACTOR LEVELS 1968-88}

Table II shows that there was a gradual improvement in all three risk factors over time for both sexes. Thus the mean serum cholesterol concentration decreased by $0.42 \mathrm{mmol} / \mathrm{l}(6.3 \%)$ for men and $0.75 \mathrm{mmol} / \mathrm{l}(10.5 \%)$ for women according to the regression line. The prediction values of the main risk factors were estimated by using Cox's proportional hazard model on survival from the Reykjavik study

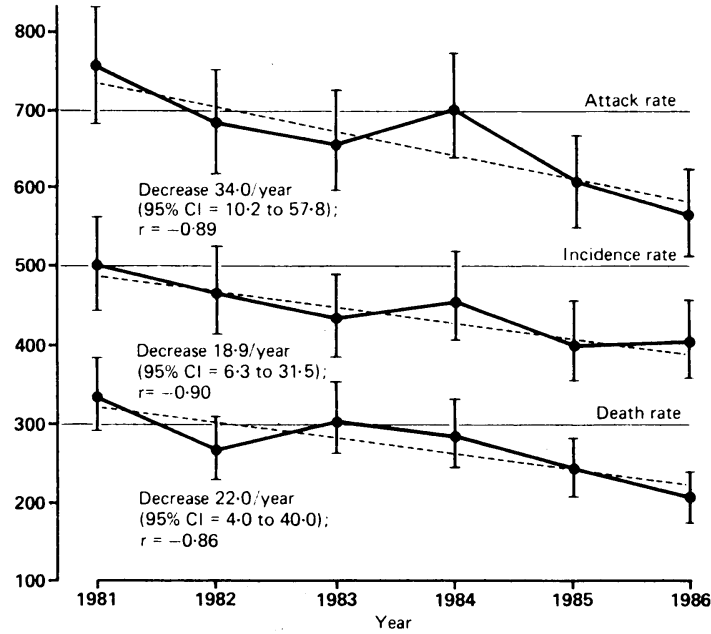

FIG 2-Myocardial infarction registration during 1981-6 amon Icelandic men aged 25-74. Rates expressed per 100000 yearly. Bars are $95 \%$ confidence intervals. Dotted lines are fitted regression lines. $C I=$ Confidence interval

$1968-85^{6}$ (unpublished results). According to that model the observed reduction in cholesterol concentration should reduce the risk of death from ischaemic heart disease by $14 \%$ in men and $17 \%$ in women.

Mean systolic blood pressure decreased by 15.5 and $19.3 \mathrm{~mm} \mathrm{Hg}$ in men and women, respectively, the risk of death from ischaemic heart disease decreasing by $17 \%$ and $24 \%$ according to the model. The proportion of subjects taking antihypertensive medication increased considerably. This treatment, however, seems to have offset the beneficial effects of lowering high blood pressure by one third, as has been reported in other prospective studies. (This finding is largely unexplained but might be related to more severe and longstanding hypertension in the treated cases. $)^{16}$

There was an overall decrease in smoking (though no fall at all in the proportion of heavy smokers), and this reduction decreased the risk of death from ischaemic heart disease by $8 \%$ in women and $13 \%$ in men.

Figure 3 shows the secular patterns in total risk attributed to the three risk factors and death rates from ischaemic heart disease observed in men and women aged 45-64. The total risk attributed to the three risk factors decreased from the beginning of the 1970s and declined by $34-37 \%$ by 1988 . This decrease in total risk corresponded closely to the observed decline in the death rate from ischaemic heart disease in the groups. For women the two curves coincided, but there was a lag of several years for men.

\section{TRENDS IN FOOD CONSUMPTION}

Patterns of food consumption changed considerably in Iceland during the observation period, resulting in a significant reduction in saturated fat consumption (table III). Whole milk consumption decreased from 280 to $150 \mathrm{~kg} /$ person/year and butter and margarine from 21.6 to $16 \cdot 8 \mathrm{~kg} /$ person/year. Low fat milk became available in 1982 and low fat butter and margarine also became available during the study period, accounting

TABLE III - Consumption of dairy products and margarine ( $\mathrm{kg} /$ person/ year)

\begin{tabular}{lrrrrr}
\hline & \multicolumn{5}{c}{ Year } \\
\cline { 2 - 6 } & 1970 & 1975 & 1980 & 1985 & 1988 \\
\hline Whole milk & $280 \cdot 0$ & $230 \cdot 0$ & $200 \cdot 0$ & $170 \cdot 0$ & $150 \cdot 0$ \\
Low fat milk & $5 \cdot 0$ & $6 \cdot 0$ & $7 \cdot 0$ & $21 \cdot 0$ & $34 \cdot 0$ \\
Skimmed milk & $4 \cdot 5$ & $6 \cdot 0$ & $5 \cdot 8$ & $6 \cdot 3$ & $12 \cdot 0$ \\
Cream & $4 \cdot 2$ & $5 \cdot 4$ & $6 \cdot 0$ & $8 \cdot 8$ & $10 \cdot 5$ \\
Cheese & $21 \cdot 6$ & $18 \cdot 4$ & $19 \cdot 8$ & $17 \cdot 6$ & $16 \cdot 8$ \\
Butter/margarine & $31 \cdot 4$ & $27 \cdot 9$ & $27 \cdot 6$ & $26 \cdot 0$ & $25 \cdot 3$ \\
\hline Total fat from these products & $31 \cdot 0$ & & & &
\end{tabular}



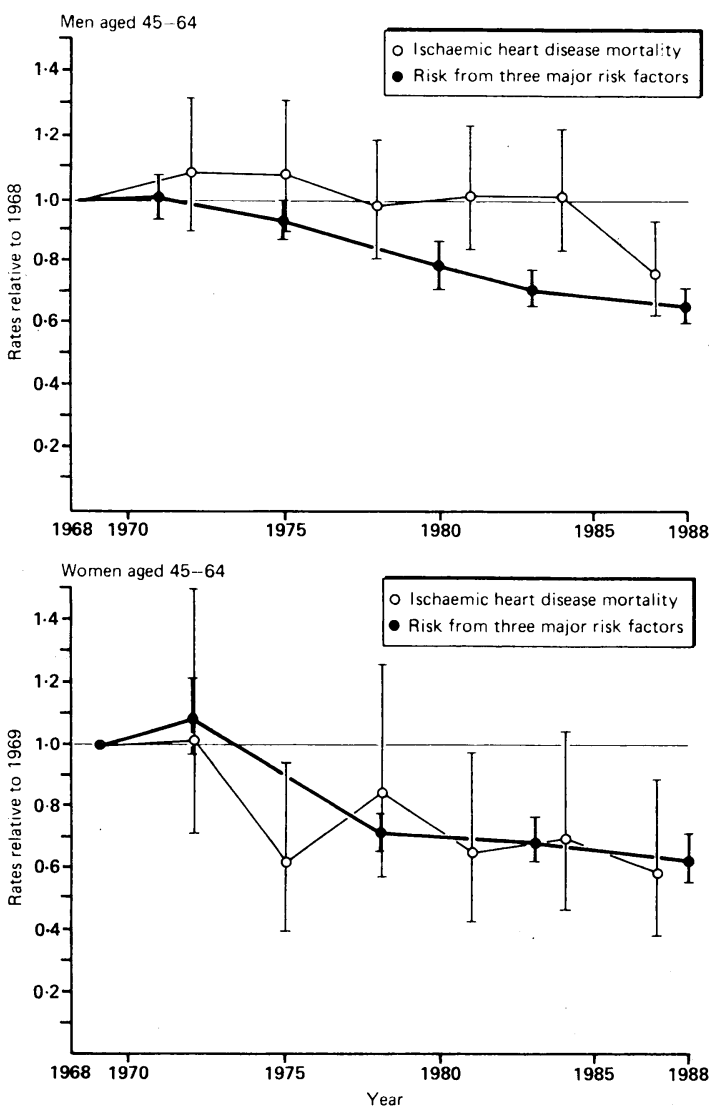

FIG 3-Observed death rates from ischaemic heart disease and calculated risks explained by major risk factors (smoking, systolic blood pressure, serum cholesterol concentration) relative to 1968 (men) blood pressure, serum cholesterol concentration) relative
and 1969 (women). Bars are $95 \%$ confidence intervals

for part of the reduction in fat from these products. Though sales of cheeses and cream increased, there was an overall reduction of $20 \%$ in dietary fat from all dairy products and margarine - that is, from a total of 86 to $69 \mathrm{~g} /$ person/day.

Total meat sales did not change appreciably during the period. Nevertheless, there was a trend towards purchase of leaner varieties such as chicken and lean beef and away from the traditional fatty lamb and mutton.

Reliable data on fish consumption are lacking. According to a household study from 1985, however, Icelanders purchased about $119 \mathrm{~kg}$ of whole fish per person yearly, ${ }^{17}$ which thereby ranked them as the largest consumers of fish in Europe. Though sales of most fatty foods declined during this period, sales of carbohydrate rich foods such as bread, fruit, and vegetables rose, and so did the sales of soft drinks and fruit juices. ${ }^{17}$ Clearly, during the period studied the overall composition of the Icelandic diet changed towards more carbohydrates and fewer saturated fats.

\section{Discussion}

Ongoing population surveys in Iceland offer an opportunity to explore time trends in risk factor levels and compare them with the mortality and morbidity due to ischaemic heart disease. Total mortality from ischaemic heart disease decreased significantly after 1985 (17\% in men, $12 \%$ in women). At the same time registrations of myocardial infarction in Iceland (MONICA project 1981-6) showed a significant decline in the incidence rate, suggesting that the reduction in mortality was largely due to a reduction in incidence. The case fatality rate did not decrease significantly. This study did not include analysis of changes in management of ischaemic heart disease during 1968-88, so their effect cannot be estimated.
It is possible that changes in death rates attributed to particular causes may be an artefact of changes in classification techniques and diagnostic fashions. The most likely shift would be into other categories of cardiovascular mortality (ICD codes 390-448). That the recent trend in total cardiovascular mortality was similar to the trend in mortality from ischaemic heart disease, however, suggests that the decline was real. Furthermore, after 1966-70 the life expectancy of 40 year old men and women in Iceland increased by 1.8 and 3.0 years respectively. According to official statistics the proportionate mortality due to ischaemic heart disease decreased from $35 \cdot 3 \%$ to $30 \cdot 5 \%$ in men and from $22.9 \%$ to $19.5 \%$ in women.

The levels of all three risk factors studied decreased over time. The Reykjavik study showed the multiplicative effects of these factors on risk. The factors themselves were nearly uncorrelated and explained about $75 \%$ of all deaths from ischaemic heart disease (see coefficients in table II $)^{6}$ (unpublished results). According to the Cox model a decrease of $0.4 \mathrm{mmol} / \mathrm{l}(6 \%)$ in the cholesterol concentration in men should decrease the risk by $14 \%$ and a reduction of $0.75 \mathrm{mmol} / 1(10.5 \%)$ in the cholesterol concentration in women should decrease the risk by $17 \%$. Most other studies have indicated that a $1 \%$ reduction in cholesterol values decreases the risk of ischaemic heart disease by $2 \%$ in men. ${ }^{18}$

Altered food habits in Iceland coincide strongly with the observed decline in serum cholesterol concentrations. Decreased consumption of dairy fat and margarine alone would be expected to lower the serum cholesterol concentration by $0.3 \mathrm{mmol} / \mathrm{l}$ according to the equation of Keys et al. ${ }^{19}$ In addition, consumption of meat fat has certainly decreased as more carcase fat is discarded during production and leaner meats have become available. Exact figures regarding these changes are, however, not available. Cholesterol values would accordingly be expected to have decreased more than $0.3 \mathrm{mmol} / \mathrm{l}$ as a result of changes in diet, as indeed they had $(0.42 \mathrm{mmol} / \mathrm{l}$ among men, $0.75 \mathrm{mmol} / \mathrm{l}$ among women). The more dramatic fall in cholesterol concentrations among women was unexplained, but possibly women changed their diet to a greater extent.

The fall in blood pressure came somewhat later, and the decrease in smoking was not apparent until after 1980.

The multiplicative effect of relatively moderate changes in all three risk factors adds up to a $34-37 \%$ decrease in risk in the age group 45-64 years. The calculated decline in risk by 1988 coincides with the observed fall in ischaemic heart disease death rates in the same age groups. This is consistent with the hypothesis that most of the decline in ischaemic heart disease in Iceland over the period can be explained by the changes observed in the three major risk factors.

Little is known about the lag between changes in risk factors in the population and changes in the incidence of ischaemic heart disease. In this study the changes in risk factors and ischaemic heart disease incidence were coincident in women whereas in men there was a lag of several years.

Studies from Great Britain, United States, Australia, and New Zealand have estimated that $30-75 \%$ of the observed decline in death rates from ischaemic heart disease was related to changes in lifestyle resulting in a fall in the three major risk factors. ${ }^{20-23}$ Most of the studies were based on mortality statistics, with little or no direct information about the individual changes in risk factor pattern, which our Icelandic surveys have offered an opportunity to observe.

1 Uemura K, Pisa $Z$. Trends in cardiovascular disease mortality in industrialized countries since 1950. World Health Stat $Q$ 1988;41:155-78. 
2 Waxveiler RJ, Beaumont JJ, Henry JA, Brown DP, Robinson CF, Ness GO, et al. A modified life-table analysis system for cohort studies. F Occup Med 1983;25:115-24

3 World Health Organisation. Proposal for the multinational monitoring of trends and determinants in cardiovascular disease and protocol (MONICA project). Geneva: WHO, 1983. (WHO/MNC/82.1)

4 Tunstall-Pedoe $H$. Diagnosis, measurement and surveillance of coronary events. Int F Epidemiol 1989;18:169-73.

5 Tuomilehto J, Kuulasmaa K. WHO MONICA project: assessing CHD mortality and morbidity. Int $\mathcal{F}$ Epidemiol 1989;18(3 suppl 1):38-45S.

6 Thorgeirsson G, Davidsson D, Sigvaldason H, Sigfusson N. Major risk factors for coronary heart disease mortality in Icelandic women. Eur Heart $f$ $1990 ; 11: 326$.

Block WD, Jarrett KJ, Levine JB. An improved automated determination of serum total cholesterol with single color reagent. Clin Chem 1966;10:681-9.

8 Rose GA, Blackburn H. Cardiovascular survey methods. Geneva: World Healt Organisation, 1968:160-2.

Cox DR. Regression models and life tables. Journal of the Royal Statistical Society 1972;34[B]:187-220.

10 Ragnarsson JO, Stefansdottir E. Icelandic nutritional survey 1979-1980. RALA report. Revkjavik: Agricultural Research Institute, 1981:74.

11 Agricultural Production Board. Arbok landbunadarins [Icelandic agricultural yearbook l. Reykjavik: APB, 1970, 1975, 1980, 1985, 1987.

12 Statistical Bureau of Iceland. Hagtidindi. Idnadarvöruframleidsla [A monthly statistical bulletin. Industrial production.] Reykjavik: SBI, 197156 (12) statistical bul

13 Breslow NE, Day NE. Statistical methods in cancer research. Vol 1. The analysis of case-control studies. Lyons: International Agency for Research on Cancer, 1980. (IARC Scientific Publications, No 32.

\section{Excess mortality associated with the HIV epidemic in England and Wales}

\section{Anna McCormick}

Office of Population Censuses and Surveys, London WC2B 6JP Anna McCormick, FFPHM, senior medical statistician

$B M \mathcal{F} 1991 ; 302: 1375-6$
14 Breslow NE, Day NE. Statistical methods in cancer research. Vol 2. The design and analysis of cohort studies. Lyons: International Agency for Research on Cancer, 1980. (IARC Scientific Publications, No 32 .)

15 Segi M. Cancer mortality for selected sites in 24 countries (1950-1957). Sendai: Toun

16 Muttiple Risk Factor Intervention Trial Research Group. Multiple risk factor intervention trial; risk factor changes and mortality results. JAMA 1982; 248:1465-77.

17 Hilmarsdottir E, Valdimarsson G, Thorkelsson G. Innlend matvaelaframleidsla [Domestic food production]. In: Manneldi og nevsla. Reykjavik: Ministry of Health and Social Security, 1989:155-88

18 Rifkind BM. Clinical trials of cholesterol lowering. Atherosclerosis Review 1988;18:59-70.

19 Keys A, Anderson J, Grande F. Serum cholesterol response to dietary fat Lancet $1957 ;$; 7887 .

20 Dobson AJ. Trends in cardiovascular risk factors in Australia, 1966-1986: evidence from prevalence surveys. Community Health Stud 1987;11(1):2-14.

21 Sytkowski PA, Kannel WB, D'Agostino RB. Changes in risk factors and the decline in mortality from cardiovascular disease. The Framingham hean study. N Engl f Med 1990;322:1635-41.

22 Dwyer T, Hetzel BS. A comparison of trends of coronary heart disease mortality in Australia, USA and England and Wales with reference to three major risk factors-hypertension, cigarette smoking and diet. Int f Epidemiol 1980:9:65-71.

23 Beaglehole R, Hay DR, Foster FH, Sharpe DN. Trends in coronary heart disease mortality and associated risk factors in New Zealand. $N Z$ Med $\mathcal{F}$ 981;93:371-5.

(Accepted 15 March 1991)
Increased mortality unattributed to but probably associated with HIV infection has been reported in the United States. ${ }^{1.3}$ Excess mortality has also been identified among HIV positive haemophiliac patients in the United Kingdom. ${ }^{4}$ A study of trends in mortality between 1984 and 1987 suggested that the increase found among single men was probably related to HIV infection. ${ }^{5}$ In this paper I examine the number of excess deaths in England and Wales in 1988 and 1989 and relate this to the HIV epidemic.

\section{Patients, methods, and results}

Draft death entries on which one of 95 selected conditions was stated to be the cause of death were identified at the Office of Population Censuses and Surveys (OPCS). These causes were selected because they had been mentioned on death certificates of people known to have had AIDS. They included 86 medical causes, including AIDS and HIV infection (International Classification of Diseases (ICD) code 279.1). Nine external causes were also included, covering drug dependence and poisoning due to various substances. The number of excess deaths was estimated by subtracting the number of deaths in 1984 from the number in each subsequent year after adjusting for population changes within each five year age group. The numbers of reports of people who died with AIDS and HIV positive people who died without developing an AIDS indicator disease were obtained from the Public Health Laboratory Service Communicable Disease Surveillance Centre (CDSC).

There were 2505 deaths due to one of the 95 causes among single men aged $15-54$ in 1989-498 (25\%) above the number expected based on rates in 1984 . AIDS or HIV infection was stated as the cause of death for only $233(47 \%)$ of the excess deaths, leaving 265 (53\%) probable HIV related deaths attributed to some other cause.

Analysis of the 86 medical causes alone showed that there were 1362 deaths among single men aged 15-54 in
1989-379 (39\%) above the number expected -233 $(61 \%)$ of which were attributed to AIDS or HIV infection. There was no similar increase among men of other marital states or among women. The increase was greatest among single men aged 30-44 and in the Thames health regions.

Analysis of the nine external causes alone, however, showed a different picture. Among single men aged $15-54$ there were 1143 deaths in $1989,119(12 \%)$ above the number expected compared with 1984. Smaller increases also occurred among men of other marita states and among women. The increase among single men was greatest among those aged 15-24 and was fairly evenly distributed across the country, suggesting that factors other than the HIV epidemic may have contributed.

In all, 376 deaths among HIV positive single men aged 15-54 were reported to CDSC in 1989, an excess of 347 compared with 1984 . If the total number of deaths reported to OPCS is used as the denominator $70 \%$ were reported to CDSC in 1989 . However, if deaths reported to OPCS due to the 86 medical causes alone is used $92 \%$ were reported to CDSC.

\section{Comment}

The associations with age, sex, marital state, and geographic location suggest that the continuing increase in the number of deaths due to the $86 \mathrm{HIV}$ related

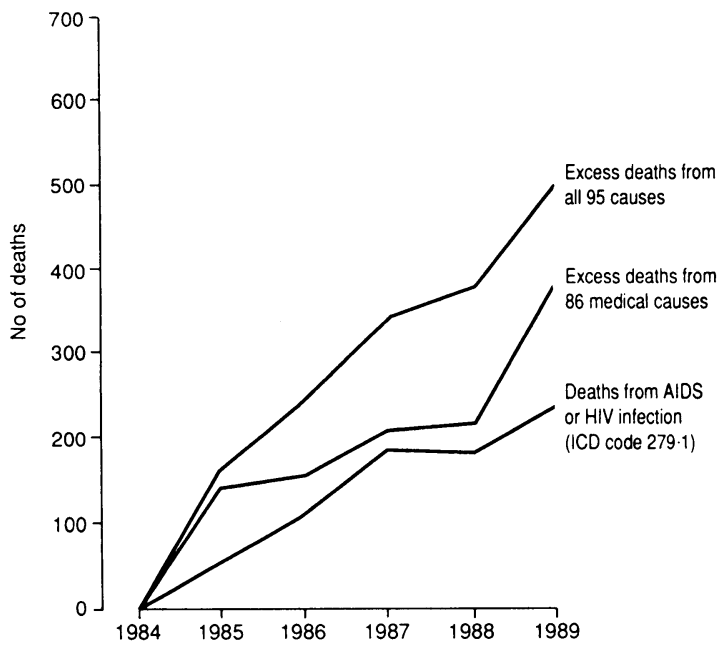

Number of excess deaths due to HIV related causes and of deaths from AIDS or HIV infection in single men aged 15-54 in England and Wales during 1985-9 compared with rates in 1984 